\section{Maintenance care for treated periodontitis patients}

\author{
Ramfjord SP: Maintenance are for treated periodontitis patients. J Clin Pertodon-
} fol 1987: 14:433-437.

\begin{abstract}
Ahstract. This paper is a review of current literature combined with clinical observations. Well-controlled maintenance care is a key consideration in the longterm prognosis of treated periodontitis patients. Periodic professional tooth cleaning every 3 to 4 months often is recommended. Furthermore. recent studies indicate a potential need for selected retreatment in problem areals. since minute residual accretions may be left behind during active therapy - even with "open" surgery. While efficient playue control is essential for optimal results during the healing phase of periodontal therapy periodic prophylaxis may prevent loss of clinical attachment over long periods of time even for patients with less that perfect oral hygiene.
\end{abstract}

\section{Sigurd P. Ramfjord}

The University of Michigan School of Dentistry, Ann Arbor. Michigan 48109
Key words: Maintenance therapy - scaling plaque control - retreatment.

Accepted tor publication 25 August 1986
If a person once has developed perjodontitis, it has to be assumed that he/ she is at risk for future loss of periodontal attachment if bacterial action is not contained in some way (Loc et al. 197\%). There is at present no "definitive periodontal treatment" that will cure atl periodontal infections in the same sense as an infection in a finger or a toe may be cured with antibiotics without residual predisposition to a recurtent infection. Periodontal disease is the result of opportunistic infection (Lang el al. $1985)$ by infective organisms which cannot be elininated from the mouth over prolonged tims. and so far we have no way to boust the patient's immunoresponses to the extent that these organisms would be innocuous. Complete periodontal health will exist only with periect plaque control, which usually is an elusive goal over a long period of time for patients who have had perioJontitis (Ramfjord et al. 1982). Obviously, the closer we come to maintenance of a placue-free dentition, the leser is the risk for return of any teriodontal disease. However the facts if life are that in spite of extensive atmpts, we have not been able to mainain complete plaque control in perioontitis patients over years, even when nrealistic amounts of time and effort ere spent towards that goal (Ramfjord ial. 1982). Fortunately, a great number $f$ individuals may harbout some plaque without even developing gingevitis, and a good $\%$ of adults have plaque and gingivitis without develop ing periodontitis. Thus dentitions may function in comtort and without measurable loss of support for the teeth over many years, in spite of less than perfect plaque control. Gingivitis has to be characterized as a form of periodontal disease with a potential over time to develop into periodontitis. From a practical public health standpoint it has been suggested that it would be very important to determine who сал loterate a centain atmount of plaque and gingivitis over tine without developing periodontitis. and only in susceptible individuals to intercept the inlective process before periodontal attachment is lost (Polson \& Goodson 1985)

To ignore gingivitis and trett only pockets which show indications of continuous breakdown would cndorse at very questionable principle of only treating "fatal disedse" (fatal 10 the teeth), and leave bleading infected gums alone untreated. One may magine how that principle could affect the practice of medicine if the physicians were to treat only discases with fatal prognosis. Quality of life and elimination of disease are after all the main concerns in all health care. although by tradition length of life may be given the primary attention

Both length of ife and quality (com- fort) of the human dentition is best served by the lowest possible atlack rate of pathogenic organisims, and all trur efforts should be directed toward a disease-free mouth. The fact that his god may not be completely anained should not be used as an excuse to ignore some form of periodonal disease (gingivitis) and treal periodontitis only. especially since what is good for gingivitis (plaque control) also is good tor control of periodontitis. Some confusion has erept into the discussion of effective mantenance progfams for gingivitis and periodontitis, since it appeats to take a longer time after troutmen 10 re-establish destructive periodontitis than gingivitis with inadequate oral hygiene by the patient. Thus, periodic professional tooth cleaning every 3 momhs may serve predictably we for prevention of clinical loss of attachment, but it may not be adequate lor prevention of gingivitis if the playue control is poor (Ramfiosd et al. 1982).

Aithough plaque control is the alpina and omega of prevention, healing, and maintenance of periodontal health. it should be understood that adequate (1) prevention programs, (2) trealment and healing programs, (3) maintenance programs may differ both in execution and time frames and still give similar results with regards to maintenance of attachment levels

This paper is focused on the mainten- 
ance care of treated periodontitis $p_{c i-}$ tients, and does not consider the need for supervision of regular dental patients without it history of periodontitis.

\section{When should maintenance phase starl?}

Maintenanes care should secure over time the results obtained by periodontal therapy. and if possible encourage regeneration of lost periodontal support (solt tisste and bone). It should preserve oral and dental health and intercept any upcoming threats 10 the health status. The duration ol inital and delayed healing responses to periodontal therapy depends on the nature of the lesions. the modality of therany and type of care during the healing stage. The initial gross clinical results of the therapeutic procedures are established 46 weeks after conplestion of the therapy (Caton $\mathrm{ct}$ al. 1982). However, there are noticuable changes in gingival form and collagen sintent for at least 6 months (or in one study for 9 months) (Badersten el al. 1984 alter completion ol the therapy. Observing patients who have had each latil of the mouth treated by dillerent achoniales, has made at apparent that adaplive changes in gingival form, crevite depth. bone contour and woth mobility may litke place over several vears even in successtully trated cases. Howsver, these adaptive changes cannot be chatracterized as healing. When healing ends. and the changes should be considered an atdaptive, cannol be stated in terms of numbers of weeks or months. The results of therapy are lairly stable

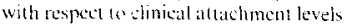
alter 6 months (Westfelt ol al. 1983). Sugestions have been made (Westedt el al. 1983) wo consider als a healing phat $s e$ the lirst o months alter completion of the treatmont of periodontal pockets. while lollowing mucogingival surgery. the results are essemtially suable after 46 weeks (Cuinard et di. \$978).

Longitudinal results following treatment of periodonitis are olter documented from is baseline of 6 (Westelt et al. 1983 ) to 12 months (Knowles et al. 1979) after the therapy. while the changes that occurred before that time usually have been credited to healing as a direct result of the therapeutic procedures. It also appears that the position of the attachment levels become stable in a much shorter time than the pocket depth and the position of the free gingival margin. However, a definite separ- ation between the bealing phase and the maintenance phase is not practical. and of minor clinical importance since the treatment procedures used during the 2 phases are in both instances concentratad on plaque control. Thus, a main question is the frequency of professional tooth cleaning needed after active treatment and how this need relates to the patjenl's own piaque control level.

It has been established that the results of treatment of periodontitis may be improved by professiona! tooth cleaning every 2 weeks for the first 6 months pustoperatively compared with prophylaxis once a month or every 3 months durng this period (Westfelt et a!. 1983). and that mechanical tooth cleaning provided slightly better results than chemical plaque control during the healing period (Westfelt et al. 1983). Later during the matintenance phasc with prophylaxis for all patients every 3 months these initial differences in results continued. The unquestionable benelit from periodic protessional tooth cleaning after periodontal surgery was established convincingly by the Gotherburg group about 10 years ago (Nyman et al. 1975). During the last 10 years of the Michigan studies, we have removed suprat and subgingival plaque professionaliy once a week for the list 4 weeks after periodontal surgery and then placed the patients on at mainenance program with visits every 3 months. What is the best during healing, ejther professional cleaning every 2 weeks for 6 months or weekiy cleaning for 4 weeks and then mantenante cate every 3 months, hats not been tested but the similarity of the results from the Gothenburg and the Michigan studies might indicate that small differences in time schedules during the intial healing are insigniticant for the clinical results.

The diastrous results from inadequate oral hygiene both during the healing phase and later have been documented convincingly by Nyman et al. (1977).

\section{Objectives of maintenance care}

The prime objective of maintenance care is to secure optimal supra and subgingival plaque control. First by encouraging optimal oral hygiene by the patient. and secondly by professional removal of all supra and subgingival playue and calculus. professional tooth cleaning should include removal of all supra and subgingival accretions with small curettes, polishing with soft rubber cups and fluoride toothpaste or fine fluorcontaining pumice, the use of the EVA polishing contrangle interproximally, and followed by topical application of fluoride. Since we have not been able to implement a perfect and uniform plaque control in periodontitis patients (Ramfjord et al. 1982), we rely heavily on the meticulous periodic supra and subgingival professional tooth cleaning and the application of fuorides The patient's own plaque control is more critical for establishment of optimat pocket depth and attachment level during the healing stage than for maintaining these levels during the maintenance phase (Ramfjord e1 al. 1982). The patients with the best oral hygiene in our studies also had the mosi favorable healing results during the 15t year (Ramfiord et al. 1982). However, later, the mantenance results werc similar over time for the groups with below or above average oral hygiene perform ance. Thus, after the ist year, the average rate of loss or gain of attachment over 7 years did not seem to be affected by the oral hygiene performance for these patients who received professiona] tooth cleaning every 3 months.

From an animal experiment (Morrison et al. 1979), it appeared that with perfect oral hygiene, periodic pro fessional looth cleaning was not needed to maintain attachment levels and teduced pocket depth. Furthermore, reports by Lindhe et al. (1984) also showed that with perfect plaque control, ireguent recill was not as important as with inadequate plaque control. However, the same group of investigators have shown convincingly that with inadequate oral hygiene and 6 months periodic recall. deepening of pockets and loss of attachment occurred (Nyman et a). 1977). Since in the Michigan studies, we have not been able 10 secure on a predictable basis perfect plaque control. we have implemonted professional tooth cleaning every 3 months, and with that program, it has been possible to maintain the chinical attachment level for the treated teeth with only few exceptions (Knowles et al. 1979. Ramfjord et al. 1986).

However. in spite of a well-controlled 3-month recall program, a few teeth have gradually lost attachment and some teeth had to be extracted (Ramfjord et al. 1986). All of these extracted teeth had specks of residual subgingival calculus which had not been 
eliminated before or during the recall. Some pockets with pus secretion and bleeding on probing also losi altachment related to ineffective root planing associated with furcations and other anatomical restrictions to access. In such instances, both professional and perional oral hygiene proved inad. equate to stop the progress of the periodontitis.

\section{Retreatment}

One very important aspect of maintenance care is to diagnose the pockets where the initial treatment was inadequate so another attempt can be made to remove irritants on the root surface. as well as to prevent significant repopulation of pathogenic bacteria in the treated pockets.

It has been suggested that need for jetreatment can be tested by bacterial counts (Keyes et al. 1978, Listgarten et a) 1981), but no specific organisms, or groups of organisms have yet been selec. tively implicated as causal agcons for chronic periodontal discase, and the sig nificance of the bacterial counts is very controversial when used for diagnosis of individual discase sites.

Although it hat been clamed on the basis of short-term studies that clinical signs of redness, bleeding on probing and suppuration are poor predictors of periodontal disease activity as measured by allachment loss (Haffajee et al. 1983). this claim should be re-evaluated wer a longer period of time and with more eases. When patients arc examined at the time of recall every 3 months. gingival bleeding 10 probing is very common and may have nothing to do wilh the status at the deeper parts of the pokets. Howaver bleoding to genty probing 23 weeks after the rocalt prophylaxis and instruction indicutes noot surface iritants. Retreatment in Litses of theeding and or pus may halt the progressive periodontitis (Ramfjord tt al. 1986), while in other instances with inaccessable furcas or residual caleutus the bleeding tendency and the breaklown may continue in spite of frequent recalls and good oral hygicne.

Incomplete removal of subgingival laque and calculus during periodontal herapy, with (Caffesse ef a]. 1985) or vithout (Rabbart at al. 1981) thap surery apparendy is more common than enerally assumed (Honter et al. 1984. aton et a]. 1985). and clinically acceptble results nay (Knowles of al. 1979.
Caffesse et al 1986) be attained in spite of the fact that microscopic remains of plaque and calculus inadvertedly may bo left on the roots, especially when deep pockets are treated. According to recent findings (Hunter et al. 1984, Eaton er al. 1985), it appeass likely that utjeroscopic specks of calculus and or plaque may be present on root surfaces tven if they appear clean 10 the ratied eye during surgical exposure, Such remaining accretions ma potentially be more-or-less harmful, dependent on total mass and type of bacleria and toxins. 'The root surtace in a pocket that hleeds during gentie probing should be rescated. and if the bleeding continues, it should be exposed surgically and planed even il no calculus is visible. Blecding on gentle probing indicates inflammation and less than ideal result of the treatment. although the pocket deph may not incroase to a measurable cxtent. Magnifying glasses should be used during periodontal surgery.

Pockets that secrete pus or bleed from the botom of the crevice during recall examination should be noted on the record and the leeth scaled as part of tho professional tooth clcaring: such par tients hould then be called back in 23 weeks to be tested by the dentist or periodontist. If the pockets still bleed, it is up to the dentist to decide what ma bo done to eliminate the source of irritation

further roos planing with or withou sturgical exposure. If the blecding is from a furcation which previously has proven to be macessibte, the looth may bo given up as an unavoidable los: or left as long as it is asymptomatic. Puckets with signilicant hoss of itlach-

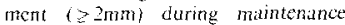
therapy should be routinely retreated. usually by is simple small mucoperiosteal flap. and the roots planed or by scailing and root planing only (Ramfjord et al. 1986$)$.

If the protessional tooth eleaning at recall visits is performed by persons who are good at scaling teeth, the chances are that calculus overlooked during the initial treatnent or previous visits is found and removed, while if the recall is mainly a supragingival plaque removal and polishing session, minute subgingival irritants are often overlooked.

Much interest is currently locused on usc of antibiotics both for treatment and maintenance case of periodontitis paients (Ciancio \& Gence 1083). However. the results from bacteriological and clinical studies are confusing, and these methods are as yet nor ready for routine clisical application. It appears that antibiotic therapy alone for periodontal disease will not provide satisfactory long-term results. Antibiotics in addition 10 mechanical therapy may enhance of least the short-term responses to the treatment, but a combination of drugs and mechanical modalities of therapy has not been shown to have any long-term advantage over periodic mochanicat recall therapy atone. However. a few patjents with recalcitrint pertiodontitis may at least over the short-term get some benefit from antibiotics in addition to the mechanical therapy (Slots el al. 1979), and it may lead to lemporary healing of a periodontal abscess. but this healing has to be augmented by mechanical therapy to assurc long-term benefit.

Problems concerning development of resistan bacterial strains (Komman \& Karl 1982), following long-term use of antibiotics arealways of concern. At the present. tetracycline is usually the drug of choice if antibiotics are to be used; however, there is a definite concensus that drug therapy. especially over prolonged lime should be avoided if satisractory results can be oblained by meshanical therapy. Even antimicrobial pockel irrigation is of limited vatue in maintenance cate (Broatz el all 1985). Professionit supra and subgingival phaque removal once a month for 3.4 months and then every 2 months for another 3-4 months has been found to be more helpful than antibiotics in recalcitrant progressive periodontitis where recall every 3 months did not slop the progress of the discase. Drugs should detinitely not bo used as a substitule for inadequate removal of root surface irritants. and in syite of all glowing reports on the merits of scaling and root planing, these are situations where flap surgery will provide better access for removal of in ritants that so-called "closed procedures".

The elenical results of mechanical periodontal therapy with regular maintenance care have beon reported to be excellent over as long as 14 years. with very few teeth lost (Lindhe \& Nyman 1984). Traditionally, it has been assunted that if probable pockel depth could be reduced to 3 mm or less following periodontal therapy, such "definitsve" or "jdeal" treatment would facilitate maintenance care and ensure agajost $\mathrm{fu}$ ture periodontal loss in that area. It has also been suggested that treated pockets 
with a forg junctional epithelium could predispose to repocketing (Barrington 1981). Research has refuted such as. sumptions (Magnusson et al. 1983. Beaumont et at. 1984. Hunter et al. 1984), and it appears from a recent study (Ramfiord et al. 1986) that the resistance to progress of periodontat disesse is about equal for a long epithelial attachment and connective tissule attachment, and that is higher $\%$ of shallow creviced ( $\leq 3 \mathrm{~mm}$ ) lost $\geq 2 \mathrm{~mm}$ of attachment ovet 5 years than for deeper crevices. Thus it appears to be no justification for a forceful penetration of the epithelial attachment during recall prophylaxis. Tightly adapled pockel walls without appreciable subgingival spread of platitt and inflammation during recall should be treated with light sealing or just poliwhed il no calculus is present.

\section{Monitoring of sensitivity, caries, pulp, old restorations and occlusion}

With gond placule controf during the healing pluse and topical acidulated thurophosphate application, root sensitivily is scldom any problem. This is parlially true because ront surlaces do not nexd to be denuded by resective surgery any more. Sodium fluoride moullarinses of sannous flusride are helpful atgainst strusitivity. Mantenanec prophylaxis should nor include rouline rest planing. Only problem areas will pecketal biceditig or pus shotild be planed al recall. Uhe ol Muorides makes the surfaces of the rools harder by uplake ol fluoride, and this hardened surlate layer should not he removed, Polishimg with theridewomaining toothpaste is indicaled rather tham use of puntice which tends 10 remove 1 on much woth subsiance. If huorides are nol uxed. the exposed root surface of ten becomes soit. and will them have to be removed by repeated roul planing. leuding to progressive loss of tooth substance

The use of topical muoride is essential for prevention of carjes. and acidulated tluorophosphate appears to be the best drug. However. if the pationt has porcelain crowns, a non-acid preparation should be used.

A thorough check for caries at least wiec a year and bilewing roentgenograms once a year both for caries and periodontal status should be carried out. Old restorations should be examined; they sometimes need to be re- placed as cracks, erosions and fractures may oceur or newer and better restoralive materials and techniques become available. Pulp vitality and old roo $\mathrm{ca}$ nal fillings should be observed with emphasis on questionable tceth according to previous records.

Occlusion, tooth mohility and masticatory comfor should atso be checked. If mobile tecth are becoming increasingly mobile or feel uncomfortable during normal mastication, splinting may be indicated. Teeth with a tendency towards tipping and elongation also need monitoring to observe if the lip. ping is progressive and whether treatment is neede. Special attention should be given to removable prosthetic appliances and their periodontal relationships. Inspection ol solt tissue lesions should always be included in maintenance care visits.

\section{Summary}

Maintenance care for treated periodontitis patiens should include professional tooth cleaning of all teeth, oral hygiene instruction and fuoride application every 3 months.

Selective retreatment is often needed during the maintenance phase, both because of residual minute accretions and in relation to new active lesions. A careful monitoring of areas with bleeding and or pus is important. Residual crevice depth after periodontal therapy is not critical for the prognosis.

\section{Zusammentassung}

Dic Nachorge be behandelien Paradontitispatienticn

Die vorliegende veröfentlichung vermittelt cine Übersicht üher das laufende Schriftum.

\section{References}

Badersten. A. Nilveus. R. \& Egelberg. I. (1984) Ejfects of non-surgical periodontal therapy.

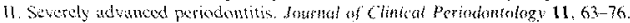

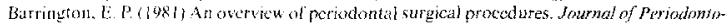
tegrit 52, 51x. $52 x$

Beaumon, R. H. O'Leary. T. I. \& Kafrawy. A. H. (1984) Relative resistance of long junctional epilhelial athesions and connective tissue atlachment to plaque induced infammation.

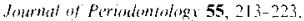

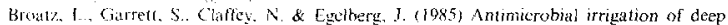
pockets to supplement non-surgical periodontal therapy. 11. Daily irrigation, Journal of

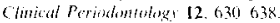

Cathesse, R. G.. SHeemey, P. L. \& Smith. B. A. (J986) Scaling and root planing with and without periodontal flap surgery. Inumat of Chmical Perindontologit. 13. 205-211.

Calon . . Prove. M. \& Folson, A (1982) Maincenance of healed periodontal pockets after a

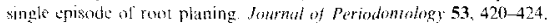

(ancis. S. C. \& Crenco. R. J. (1983) The use of antibiolics in periodonlal diseases. Interta-

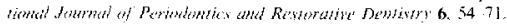

faton, K. A. Kieser. I. B. \& Davies, R. M. (1985) The removal of root surface diposits.

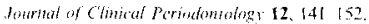

Cininatd. E. A. \& (atfesse. R. (i. (1978) Treatmett of healized gingival recessions. Part IIl. Comparison ol resulis oblained with kateral sliding and coronally repositioned llaps. fownd

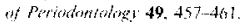

Halfajec, A. E.. Sucransky. S. S. \& Goodson. I. M.: Clinical parameters as predictors of destructive periodontal disease activity. Joumof of Climical Periodontology $10,257.265$

llunter. R. K. Oleary. T. I. \& Kafrauv. A. H. (1984) The eflectiveness of hand versus ultrasonic instrumentation in open flap sont planing. Journal of Periotontology 55. 697-703.

Kiyes. P. H. Wrighi, W. E. \& Howard. S. A. (1978) The use of phase-contrasi mieroscopy and chemotherapy in the diagtiosis and treatment of periodontal lesions - an initial report. Quintestonce Intrhational 9,69-76.

Knowles, J. W., Burgett. F. G.. Nissle. R. R.. Shick, R. A.. Morrison, E. C. \& Ramfjord, S. P. (1979) Results of periodontal treatment related to pocket depth and attachment leve? Eight years. Jommal of Poriodontologgr50. 225-23.

Kornman. K. S. \& Kar!. E. H. (1982) The effect of long-term. low-dose tetracycline therapy on the subgingival microflora in refractory adult periodontitis. Jenunaf of Pariodomfics $\mathbf{5 3}$, (0) 4.610

Lang. N. P. Gusherti. F. A \& Sicgrist. B. E. (1985) Aetiologie der Parodontalerkrankungen. Arta Parodontotogica 14, 1-12.

Lindhe, J, \& Nyman. S. (1984) Long-term maintenance of patients treated for advanced periodontal disease Jommal of Climical Periodontolugy 11,504 514 
verbunden mit klinischen Beobachlungen. Die gut kontrollierte Nachsorge nimm bei der Langzeitprognose behandelter Parodontitispatienten eine Schlüsselstellung ein. Im allyemeinen wird eine, in 3 bis 4-monatlichen Abständen vorzunehmende, professionejle Zahnreinigung emplohlen. Weiterhin zeigen kürzich veröfentlichte Studien den potentiellen Bedarf an selektiver Bchandiung von Problemregionen, da nach der aktiven Therapie kleine Residualloci mit Krankheitszuwachspolential übrig gebicben sein künnen - auch nach "offenes" Chirurgie. Während die erfolgreiche Plaquekontrolle die Voraussetzung für optimake Ergebnisse während der Heilungsphase de parodontalen Therapic isl. so kann die regelmässig vorgenommenc Profylaxe cine Verlust klinischen Attachments auch bei Pationten verhindern. deren orale Hygiene weniger perfekt ist

\section{Résumé}

Soins de maintien chez les patients traites pout parodentiles

Cet article contient une revue de la litterature acluelłe en même temps que des observations cliniques. La qualité du programme des soins de maintien est un élement fondanental pour le pronostic à long terme chez les patients qui ont subi un traitement parodontal. Il est souvent recommandé de faire des seances de nettoyage dentaire professionnel tous lis 3-4 mois. Des études recentes ont on outre indiqué qu'il peut être nécossaife de faite unc reprise selcetive du traitertiont dans les zones problematiques. puisqua des restes minimes de dépôts peuvent subsistes apres le trailement actif, même dans ke cas dunte intervention chirurgicale à decouvert. Le controble affictae de la playue est essenticl pour obtenir line resultal optimal pendant la phase de guierison du railement parodontal, mais les netloyages dentaires périodiques peuvent prévenir la perte diallache clinique sur de longues periodes, mine si les soins d'hygiène pratiques par les patients ne som pas parfaits
Lindhe, J., Westfelt, F.. Nyman, S. Socransky, S. \& Hallajee, A. D. (1984) Long lerm eflect of surgical inon-surgical treatment of periodontal disease. Journal u/ Clinic al Periodomologer 11. 548558 .

Listgarten, M. A. \& L.evin, S. (198I) Posilive correlation between the proportions of subging]val spirochetes and motile bacleria and susceptibility of human subjects to periudonkal determitulion. Journal of Chinicul Periodonalogr. $8,122 \cdots 138$.

Loe. H.. Anerud. A. Boysen, H. \& Smith, M. (197k) The natural history of periodontal disease in man. The rale of periodontal destruction before 40 years of age. Jmirnd of Poriodentroligy 49. 607.620.

Magnusson. 1., Runsiad. L. Nyman. S. \& Lindhe, J. (1983) A long junctional epithelium. A

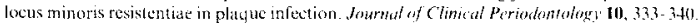

Morrison. E. C., Lang. N. P. I. Inc. II. \& Ramfjord, S. P. (1979) Effects of repented scating and ron planing and or controlled oral hygiene on the periodontal atlichment level and pocket depth in Beagle dogs. 1. Clincal lindings. Imamal of Periodonfal Resedarth 14. 428-437.

Nyman, S., Rosling 8. \& Lindhe, J. (1975) Elfet of prolessional woth cletuing on healing

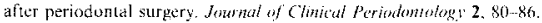

Nyman. S., Lindhe, I. \& Rosling. B. (1977) Periodontal surgery in platque infected dentilions. Jounut of (linicat Poridoniofogr 4, 240).244.

Polson, A. M. \& Gondson. J. M. (1985) Periodonal diagnosis, Current stalus and luture

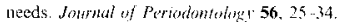

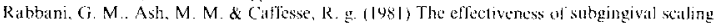
and rool planing in cakulus removal. Jommat of Pariedendedogr 52. 119-123.

Rampjord. S. P. Morrison, F. C... Burgett, F. G. Nissle, R. R. Shick, R, A., Zann, (i I. \& Knowles, I. W. (1982) Oral hygine and maintenance of periodnntal support. Jourat of Porichantologi 53, 26-30.

Ramljord, S. P. Caffesse. R. G., Morrison. E. C., Hill, R. W. Kerry, G. J, Appleberry. E A.. Nissle. R. R. \& Siults, D. L. (1987) 4 modatities of periodontal truatment compared over 5 years. Aoumul of Clinical Paridomtology 14. 445452

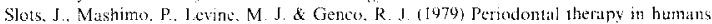
1. Microbiological and clinical elfects of a single coume of periobontal sealme and rom

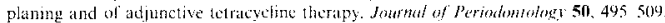

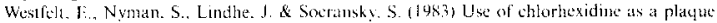
control measure following suraked treatment of periodontal divease. format of clinical Perientontelegr 10.22 30

Westlelt. I:. Nyman. S. Socransky. S. \& Lindhe, I. (iv83) Sigmiteanes of frequency of

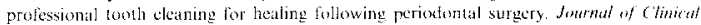

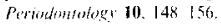

Addiress:

Sigurd P Ramfingd

The Untersit of Michion

Siluol of Domint

Depertmon of Petiodomation

Am Arbor, Michigem 48709

LS. 4 
This document is a scanned copy of a printed document. No warranty is given about the accuracy of the copy. Users should refer to the original published version of the material. 